\title{
Industrial relations and labour market segmentation in Dutch call centres
}

Citation for published version (APA):

van Jaarsveld, D., de Grip, A., \& Sieben, I. J. P. (2009). Industrial relations and labour market segmentation in Dutch call centres. European Journal of Industrial Relations, 15(4), 417-435. https://doi.org/10.1177/0959680109344369

Document status and date:

Published: 01/01/2009

DOI:

10.1177/0959680109344369

Document Version:

Publisher's PDF, also known as Version of record

Document license:

Taverne

Please check the document version of this publication:

- A submitted manuscript is the version of the article upon submission and before peer-review. There can be important differences between the submitted version and the official published version of record.

People interested in the research are advised to contact the author for the final version of the publication, or visit the DOI to the publisher's website.

- The final author version and the galley proof are versions of the publication after peer review.

- The final published version features the final layout of the paper including the volume, issue and page numbers.

Link to publication

\footnotetext{
General rights rights.

- You may freely distribute the URL identifying the publication in the public portal. please follow below link for the End User Agreement:

www.umlib.nl/taverne-license

Take down policy

If you believe that this document breaches copyright please contact us at:

repository@maastrichtuniversity.nl

providing details and we will investigate your claim.
}

Copyright and moral rights for the publications made accessible in the public portal are retained by the authors and/or other copyright owners and it is a condition of accessing publications that users recognise and abide by the legal requirements associated with these

- Users may download and print one copy of any publication from the public portal for the purpose of private study or research.

- You may not further distribute the material or use it for any profit-making activity or commercial gain

If the publication is distributed under the terms of Article $25 \mathrm{fa}$ of the Dutch Copyright Act, indicated by the "Taverne" license above, 
(C) The Author(s), 2009. Reprints and permissions: http://www.sagepub.co.uk/journalsPermissions.nav

Volume 15 Number 4 pp 417-435 www.sagepublications.com

\title{
Danielle van Jaarsveld, Andries de Grip and Inge Sieben
}

University of British Columbia, CANADA, Maastricht University, The NetherLands and Tilburg University, The NetherLANDS

\section{Industrial Relations and Labour Market Segmentation in Dutch Call Centres}

\begin{abstract}
This article uses qualitative and quantitative evidence from call centres to show how the Dutch industrial relations system balances employer needs for workforce flexibility with the interests of employees. The normalization of temporary agency work in the Netherlands helps employers build workforce flexibility, reducing pressures on firms to subcontract work and to escape the existing regulatory system. In addition, the inclusiveness of the Dutch collective bargaining system, with the majority of call centre workers covered by a collective agreement, reduces differences in working conditions. Nonetheless, variations in negotiated agreements covering in-house workers, subcontractors and temporary agency workers lead to tiers of segmentation among these secondary labour market jobs.
\end{abstract}

KEYWORDS: call centres - Dutch labour relations - labour market segmentation - temporary agency work

The Netherlands is an especially interesting laboratory for examining service work because it has one of the largest service economies among coordinated market economies, and undoubtedly this has influenced its industrial relations system (Visser, 2002). In response to a dramatic economic crisis during the 1980s and a recession in the early 1990s, labour market stakeholders developed innovative measures to enable employers to build a flexible workforce while providing greater stability for nonstandard employees (Visser and Hemerijck, 1997). These measures encouraged further growth of the already large non-standard workforce, offering employers an alternative to strict dismissal regulations and other rigidities inherent in the Dutch industrial relations system.

For call centres, one exemplar of service work, access to a flexible workforce is especially important given that these workplaces need to adjust workforce size in response to demand fluctuations (Batt and Moynihan, 2002). We use evidence from call centres in the Netherlands to address two research questions. First, how far does the Dutch industrial relations 
system offset the downside of these work arrangements? Second, in what ways does it influence the type of labour segmentation in Dutch call centres?

We answer these questions with quantitative and qualitative evidence collected through a survey and ten site visits as part of the Global Call Centre Study. First, the survey was administered in 2004 as part of an annual national survey of call centres in the Netherlands in conjunction with the National Contact Center Benchmark Platform (NCCBP). Second, between 2003 and 2004 we visited seven in-house and three subcontractor call centres, employing between 100 and 2500 full-time equivalent (FTE) customer service representatives. Interviewees included the centre manager, HR managers, supervisors and customer service representatives. Third, we also interviewed managers of temporary employment agencies that have call centres as clients. Finally, we interviewed delegates of social partners involved with call centres including Vereniging Contactcenters Nederland (VCN), the largest employers' association for in-house call centres, Werkgeversvereniging Callcenters (WGCC), the largest association for subcontractor centres, and FNV Bondgenoten, the largest union in the sector.

We argue that the Dutch industrial relations system helps call centre employers build workforce flexibility, thereby reducing pressures to subcontract work. Certain unique aspects of the Dutch system, including the central role of temporary agencies, have important implications for the forms of labour market segmentation we find in call centres. We find evidence of four tiers of jobs, outcomes of the variations in collective agreements according to the type of call centre, the agent's employment status and the relationship between the call centre and temporary employment agencies.

In many respects, call centre workers are similar to temporary agency workers, with low pay, short tenure and high intra-firm mobility (de Grip et al., 2005). Therefore, we compare the call centre and temporary agency sectors, examining how Dutch unions are responding to the expansion of call centre work and the challenges these workplaces present to existing institutional remedies. In addition, we compare the Dutch case to the other countries included in this issue to provide a broader context for our findings. In the next section we provide institutional background; then we analyse evidence on the ability of the Dutch industrial relations system to influence working conditions.

\section{The Dutch Industrial Relations System}

The Dutch industrial relations system features close collaboration and consultation among social partners. Wage bargaining is highly centralized. 
Tripartite national negotiations establish guidelines for wage agreements at the sector level (although recently there has also been a growth of company-level bargaining) (SER, 2007). Once a sectoral agreement is reached, the government can declare it generally binding for all firms in the sector except those with a separate company-level agreement (Teulings and Hartog, 1998). Thus collective agreements cover 85 percent of all employees, regardless of whether the employees are union members (SER, 2007). In fact, union density is fairly low, in part because Dutch unions do not have a tradition of servicing their membership at the workplace (Visser, 1998). Strikes are fairly rare because of the collaborative approach to labour market policy, and several collective agreements include a peace clause.

Works councils were established by law in 1950 and are currently obligatory in all workplaces with 50 employees or more (Looise and Drucker, 2003). As in Germany, councils are employee-only bodies; trade unions can nominate slates but non-union candidates may also stand. They have similar powers to their German counterparts (particularly in firms with over 100 employees), but in general make less effective use of their rights, partly because of weaker involvement by the unions (GumbrellMcCormick and Hyman, forthcoming; Streeck, 1995; Visser, 1995).

The collaborative tone of Dutch industrial relations coupled with the economic crisis in the 1980s and 1990s helped stakeholders adapt to pressures for labour market flexibility while at the same time protecting working conditions. New legislation reduced protections for regular employees and improved those for non-standard workers, and this 'flexicurity' combination has become the distinctive feature of the Dutch model. The social partners in the Netherlands also renegotiated employment policy on the basis of wage moderation through the 1982 Wassenaar Accord, which ended wage indexation and enacted cost-neutral worktime reductions and job-sharing (Hemerijck and Vail, 2006).

Two laws in the late 1990s, the 1998 Wet Allocatie Arbeidskrachten door Intermediairs and the 1999 Wet Flexibiliteit en Zekerheid, were designed to balance employers' needs for workforce flexibility with employment security for temporary agency workers (Arrowsmith, 2006; Tijdens et al., 2006). The first removed the licensing system for temporary employment agencies and required user firms to compensate agency workers at the same rate of pay as in-house workers performing similar types of work but permitted derogation from this principle in collective agreements (Storrie, 2002; Tijdens et al., 2006). The second established a set of rights for temporary employees that progress through four phases, with employee rights increasing with tenure (Tijdens et al., 2006). Under the four-phase system, during the first 26 weeks (phase 1), a temporary worker could be fired at will, but after 36 months of continuous employment or three successive contracts with the same employer, the temporary 
worker receives an indefinite contract with the employer (Koene et al., 2004). These rights were further developed and revised into a three-phase system in collective agreements. These legislative measures sought to minimize employer abuse of these types of employment arrangements, a reality that came to light in some US companies where workers were trapped in long-term temporary positions without access to benefits (van Jaarsveld, 2004).

These legislative measures have helped to normalize temporary agency work in the Dutch labour market, and its use is viewed less negatively by the workforce than in other countries. Mobility exists for temporary workers who prefer indefinite contracts. At the same time, some individuals prefer to work fewer hours, and so, temporary work offers them the opportunity to remain in the workforce. For example, many women with children who still want to participate in the workforce prefer to do so in part-time and temporary positions (Visser, 2002).

In addition to legislated rights, collective agreements for the temporary agency sector have narrowed to some degree the differences between standard and temporary employment arrangements. While other countries have collective agreements that cover temporary workers, the Netherlands and Sweden have the most comprehensive systems (Storrie, 2002). Since 1985, well before the countries discussed in the companion articles to ours, the majority of temporary workers in the Netherlands have been covered by a sectoral agreement between the Algemene Bond Uitzendondernemingen (ABU, General Association of Staffing Agencies), the main Dutch trade union Federatie Nederlandse Vakbeweging (FNV) and two smaller unions, the Christelijk Nationaal Vakverbond (CNV) and De Unie (Storrie, 2002). The agreement deviates from the legislative requirements: for example, equal pay for agency workers is not triggered until after 26 weeks; they remain employed on an at-will contract with varying levels of notice for the first 78 weeks; and they obtain an indefinite contract only after working for 3.5 years with the agency (Arrowsmith, 2006; Tijdens et al., 2006). A second collective agreement, between Nederlandse Bond van Bemiddelings- en Uitzendondernemingen (an employers' association representing temporary agencies) and Landelijke Belangenvereniging (a minority union) covers only 6 percent of agency workers (Tijdens et al., 2006).

Historically, unions have been concerned about firms hiring temporary workers because these practices create a segmented labour market consisting of permanent, well-paid jobs with career prospects in the primary segment and short-term, low wage jobs with limited career prospects in the secondary segment (Doeringer and Piore, 1971). In general, less educated workers occupy jobs in the secondary market. Dekker et al. (2002), however, have shown that the character of the secondary labour market in the Netherlands is undergoing a transformation in this respect, 
with temporary work also attracting those with secondary or higher education. In the next section, we use evidence from our survey data and qualitative research to evaluate how the Dutch industrial relations system is coping with call centre work.

\section{The Dutch Industrial Relations System: Call Centres and Temporary Agencies}

As with the temporary agency sector, the Netherlands has been a leader in the development of a sectoral agreement covering call centre subcontractors. In-house centres, where firms serve their own customers, are covered by their own sectoral agreements; the Vereniging Contactcenters Nederland (VCN), established in 2003, promotes the interests of inhouse call centres but does not participate directly in collective bargaining, since sector specific employers' associations are more relevant to represent a firm's interests. The FNV is by far the largest trade union confederation, and is involved in 500 of the 900 collective agreements current in the Netherlands. The majority of call centre employees are represented by two of its affiliates: FNV Bondgenoten, an alliance of FNV unions that represents workers in the manufacturing and commercial services sector (overall membership 465,000), and AbvaKabo, which represents call centre employees employed in the public sector (overall membership 360,000). Call centre employees are also represented by Qlix (until 2009, Bond voor Telecompersoneel) and CNV. Customer service representatives who are hired through temporary agencies are represented by Dienstenbond CNV, FNV Bondgenoten and De Unie; the latter is an affiliate of Middelbaar en Hoger Personeel (MHP), the Federation of Managerial and Professional Staff Unions.

The inclusiveness of the Dutch industrial relations system is reflected in the high percentage of call centres participating in collective agreements, and the widespread presence of works councils. In-house call centres are more likely to participate in a collective agreement ( 78 percent) than subcontractors (43 percent). However, it should be noted that in practice all call centres are covered by collective agreements, as in the Netherlands the government usually extends the scope of sectoral agreements to cover companies that are not affiliated with an employers' association that is a party to the relevant collective agreement. This algemeen verbindend verklaring (declaration of universal applicability) aims to protect firms participating in collective agreements from competitors seeking an advantage in their sales markets by providing worse pay and labour conditions. Despite these coverage levels, official union membership among call centre agents is very low, consistent with other industries. 
Collective bargaining coverage is considerably lower in the subcontractor segment, because its agreement is a recent development. In 1998, an employers' association, the Werkgeversvereniging Callcenters (WGCC), was formed to represent subcontractor call centre employers. In 2003, the WGCC represented 26 of approximately 250 subcontractor call centres in the Netherlands, covering half of all subcontractor call centre jobs (interview data).

In Table 1, we compare the terms of collective agreements in traditional sectors, such as banking, with the temporary agency sector, and the recently developed collective agreement covering subcontractor call centres.

In 2003, the WGCC and FNV Bondgenoten negotiated the first Dutch agreement for subcontractor call centres. The agreement included provisions regarding probationary periods, the working week, salary, holidays and special leave, overtime compensation, sickness benefits and travelling expenses (see Table 1). The government declared this agreement generally binding for all subcontracting firms, to prevent other subcontractor firms from gaining an unfair competitive advantage. Employers signed this collective agreement to professionalize the sector and improve the image of call centre work in response to recruitment problems and escalating turnover rates (interview data). This collective agreement had its origins in a company agreement at SNT, one of the largest and longest-established Dutch subcontractor, formerly the call centre operations of the telecommunications company KPN and an active member of the WGCC. A legacy of its ties to a former public company, SNT had a relatively high rate of union membership amongst its agents compared with other subcontractor call centres.

In May 2004, WGCC and FNV Bondgenoten began negotiations for a new agreement. FNV tried to expand protections for employees by adding a pension scheme and a job classification system, but WGCC refused. A year later, WGCC and a much smaller union, the Bond voor Telecompersoneel, negotiated a 17 -month agreement that included a wage increase, sick pay and the introduction of a new grade for jobs requiring complex skills. The 2005 collective agreement introduced a certification programme for employees, providing agents with a so-called 'starter permit'. Both parties agreed to investigate a flexible lump-sum scheme for employees to contribute to a pension and child care. This tailor-made approach goes a step further than the decentralization trend in the Netherlands, in which individual negotiators or employees can select from a menu of benefit options (van der Meer et al., 2005). Still, the cost of this customized solution may be much lower than traditional employment terms existing elsewhere in the Dutch economy. Although FNV Bondgenoten refused to endorse the 2005 agreement on the grounds 


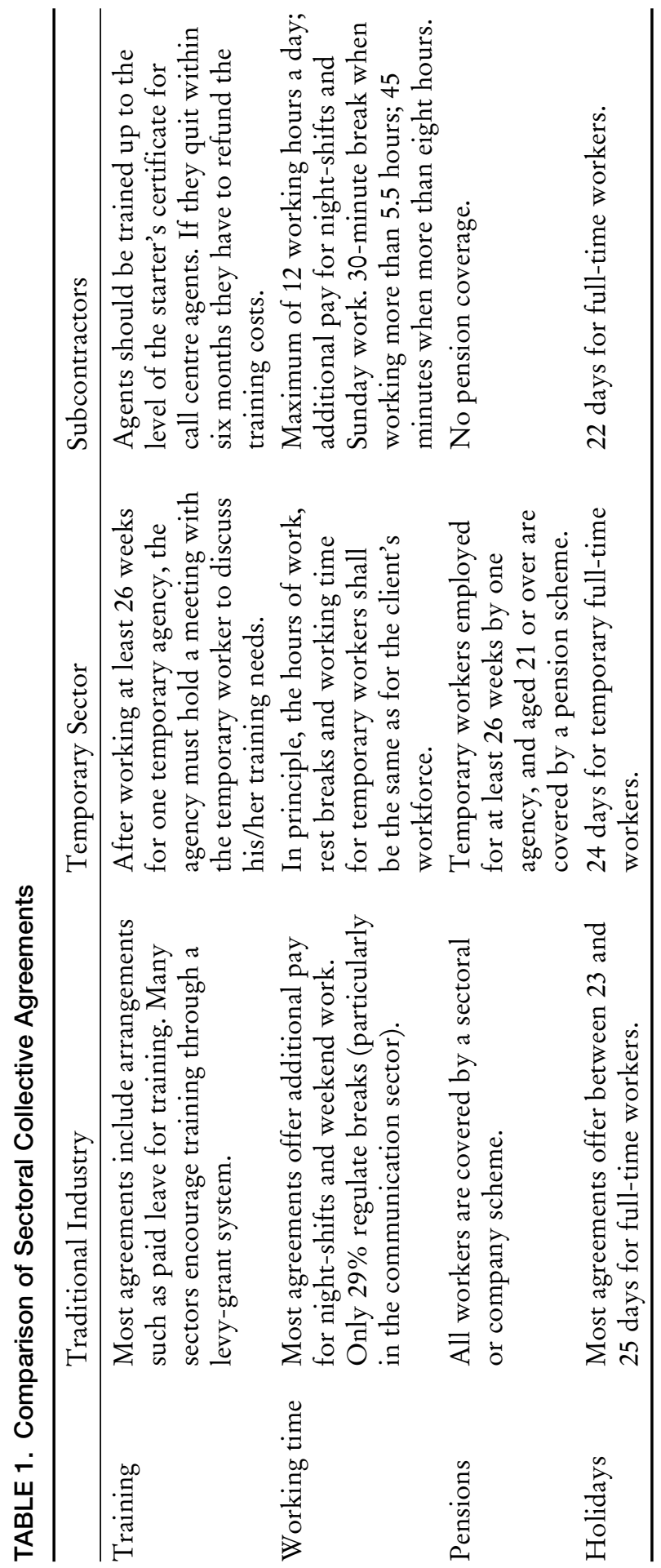


that the union which negotiated it did not adequately represent the majority of the call centre workforce, the government declared the collective agreement binding for all subcontractor call centres.

In 2006, the employers decided to offer recognized terms of employment to address recruitment and retention problems, and WGCC negotiated a new collective agreement with FNV Bondgenoten. The decision to bargain once again with $F N V$ Bondgenoten shows that employers can encounter difficulties when they pursue an alternative route in labour relations, because it can harm both the general image of the sector and firms' recruitment potential in the labour market. Before the 2006 agreement was settled, some subcontractors offered their agents a pension scheme in order to prevent a large outflow to neighbouring call centres (van Klaveren and Sprenger, 2008). In 2008, WGCC and FNV Bondgenoten along with the Bond voor Telecompersoneel signed a third collective agreement with a two-year duration. This did not include a pension scheme, but both sides are committed to moving towards one.

The development of a subcontractor collective agreement in the Netherlands has some similarities to the other countries examined in this issue. In France, two collective agreements were extended to subcontractor call centres: one for subcontractors owned by telecommunications firms, and one for the tertiary sector. The French agreement for service firms in the tertiary sector, like the Dutch version, offers statutory minimum protections to the front-line workforce, and two unions refused to sign (Béraud et al., 2008). Since 1998, subcontractor call centres in Austria have had a collective agreement (Holst, 2008; Shire et al., this issue). Meanwhile, in Germany and Denmark, industry agreements for subcontractor call centres are non-existent because of different dynamics in the relationship between in-house firms and subcontractor subsidiaries, the lack of actors with enough power to facilitate such an agreement and the absence or less common use of mandatory extension clauses (Doellgast et al., this issue; Sørensen and Weinkopf, this issue).

Beyond collective agreements, and unions, works councils also represent the interests of employees but have less influence on call centre working conditions in the Netherlands, because call centre employees lack a strong voice on these councils. As Table 2 illustrates, although 96 percent of in-house call centres and 76 percent of subcontractors in our study have a works council, only 56 and 48 percent of councils respectively have representation from customer service representatives.

This difference may be explained by the relative youth of the subcontractor industry in the Netherlands compared to in-house centres, where works councils have a longer, deeper presence. In the subcontractor centres, our interviews with managers and survey data revealed that the 
TABLE 2. Characteristics of Dutch Call Centres and Workforces (\%)

\begin{tabular}{lllll}
\hline & Total & In-house & Subcontractor & Sig. \\
\hline Institutional characteristics & & & & \\
Collective agreement & 68 & 77 & 45 & $* *$ \\
Works council & 91 & 96 & 76 & $* * \%$ \\
$\quad$ Works council with agents & 54 & 56 & 48 & \\
$\quad$ represented & & & & $*$ \\
Workforce composition & 28 & 24 & 39 & \\
Aged under 25 & 18 & 15 & 24 & \\
Vocational or university & & & & \\
$\quad$ qualification & 64 & 59 & 77 & \\
Part-time & 19 & 16 & 25 & \\
Temporary & & & & \\
\hline
\end{tabular}

$* * * p<.001 ; * p<.005 ; * p<.01$.

quality of representation is low on account of high turnover and the short tenure of customer service representatives. Call centre agents are more likely to participate on works councils in in-house call centres in financial services, telecommunications, business services and the IT sector.

Nevertheless, there are substantial differences for workers according to the collective agreement applying to them, as Table 1 shows. In a call centre workplace some agents may be governed by a firm's sectoral agreement whereas others may be covered by the temporary agency sector agreement. In general, agency workers are covered by the latter agreement, and its terms exceed the protections outlined in the relatively nascent subcontractor collective agreement. The disparities between these two collective agreements create an incentive for Dutch subcontractor call centres to hire employees under the WGCC collective agreement. For example, they can avoid obligations associated with the temporary agency sector agreement such as paying additional compensation for evening overtime.

This means that the rules governing these establishments are distinct, creating differences in labour market conditions and outcomes for workers, despite the inclusiveness of the Dutch system. Within centres, the layers of collective agreements (for those hired through temporary agencies, and those who are directly hired by the user firm) allows for some escape from stronger collective agreements to weaker ones. Dutch call centre managers often rely on temporary personnel to cope with business fluctuations during the course of a year: 61 percent of in-house call centres and 74 percent of subcontractor call centres employ temporary 
staff hired through an agency (de Grip et al., 2005). On the one hand, call centre employers can enhance workforce flexibility while operating within the Dutch industrial relations system. On the other hand, the staffing mixture can raise some challenges because some customer service representatives are covered by the firm's sectoral agreement whereas others are covered by the temporary agency agreement. While some researchers have noted the fragmentation of the collective bargaining system in other countries because call centres cross industrial boundaries (Doellgast and Greer, 2007), the mix of staffing arrangements within centres means that agents who perform the same work may be working under a very different set of employment conditions.

Beyond shifting some employees to weaker collective agreements, some call centre employers have also tried to escape the inclusive system by altering their organizational structure. For example, the national telephone company KPN established a stand-alone subcontracting firm, SNT, enabling the latter to negotiate a separate agreement with $A b v a K a b o$ that included 40 percent lower salaries and lower benefit offerings than the KPN collective agreement (van Klaveren and Sprenger, 2008). The KPN collective agreement with AbvaKabo consisted of much more comprehensive protections than the more recent SNT collective agreement (de Grip et al., 2005). The banking and airline sectors also offer examples of firms trying to avoid the Dutch industrial relations system. Although in both sectors, call centre employees were covered by sectoral agreements, the ABN-AMRO bank and the former Dutch national airline KLM tried to reduce working conditions below the level of the terms in the sectoral agreement in newly established call centres (Bain and Taylor, 2002). The Dutch Industrial Court ruled against ABNAMRO and in favour of KLM, but both abandoned their plans (Bain and Taylor, 2002).

The Dutch industrial relations system has adapted somewhat to call centre work, as illustrated by the coverage of collective agreements and presence of works councils. The difficulties encountered in negotiating the 2005 subcontractor agreement illustrate how a new industrial sector, with personnel working in the secondary segment of the labour market, does not easily conform to the regular Dutch industrial relations model. At the same time, however, there are clear parallels between the characteristics of call centre work and the temporary agency sector, which took 15 years for a comprehensive collective agreement to be developed; in the call centre sector this goal may be achieved sooner, benefiting from the lessons learned by unions and employers within the temporary agency sector. Still, the unique institutionalization of workforce flexibility in the Netherlands means that there are fewer incentives for firms to operate outside the traditional institutional system. 


\section{Are New Forms of Labour Market Segmentation Emerging?}

The working conditions for the call centre workforce in the Netherlands depend on the type of centre that employs them and the collective agreement they are under. In in-house centres, decent sectoral contract conditions encourage firms to invest in training, and opportunities for career advancement exist within and outside of the call centre although wage levels for call centre agents are relatively low.

For those employed in in-house centres with an indefinite contract, working conditions are consistent with good jobs in the secondary segment of the labour market, and are better than for agents hired through temporary agencies. Consistent with this model, in-house centres offer significantly more training (21 days on average) compared with subcontractor centres (six days). This employment system survives in the Netherlands because of the availability of a temporary workforce willing to serve as a buffer for agents on indefinite contracts who are very difficult to dismiss, and as a means to identify high performers who can be promoted to indefinite contracts or out of the call centre. In this manner, the temporary agency sector - because its collective agreement is weaker than that for the user firm - offers in-house centres the opportunity to access a less expensive workforce that can be more easily dismissed should market conditions change.

In-house centres and subcontractors also differ in how they use temporary agencies, and this has important implications for the quality of jobs and working conditions for employees. In many in-house centres, temporary employment agencies have assumed responsibilities beyond recruitment. In essence, in-house centres have outsourced some of the human resource responsibilities for a segment of their workforce to temporary employment agencies. After running the initial hiring and selection process, they may also deliver basic training in conversation techniques and customer service, and coach temporary agents. Among those in-house centres that have a dedicated relationship with a temporary agency, the agency will place staff onsite on a permanent basis to support the temporary staff, handling a range of human resources responsibilities including planning, handling invoices, retention management and performance evaluation. The close relationship between the temporary agency and the in-house call centre means that supervisors can focus on the permanent staff who generally handle higher value clients (interview data).

For example, in a financial services centre we found that a temporary agency initially screens all applicants for agent positions to determine whether they have an appropriate voice for call centre work, and to verify that they meet the educational criteria. If selected by one of the 
four temporary agencies the centre uses, the applicant's CV is passed onto the call centre's manager. If the applicant successfully passes an interview with the manager, the final interview stage involves a telephone assessment of the individual conducted by an external firm. While this selection process might appear to be quite extensive for a customer service position, it makes sense given that these jobs are an entry point for other positions in the company. As one manager explained, 'the call centre is a first step to get a career at the bank'.

The temporary agency sector agreement has weaker terms than the financial services agreement, offering this firm the opportunity to escape from the stronger agreement for a segment of its workforce. Once hired, the financial services firm can choose under which collective agreement they want to hire agents - either the firm's collective agreement or the temporary agency's agreement. A newly hired agent receives six weeks of training about the products, operational systems and the handling of customers. In this centre, 40 percent of agents have temporary contracts with an agency and are covered by the temporary agency collective agreement. If the employee performs well, the employee will be offered a fulltime contract covered by the financial services collective agreement. Three levels of agents exist: those who perform well on one task such as sales or service; those who handle any type of call (inbound, outbound, sales, service); and highly skilled agents who handle high-value transactions and new projects (interview data). In this centre, in-house agents work on average 30 hours per week in financial services and earn $€ 13.80$ an hour (de Grip et al., 2005).

In financial services call centres, the wholesale outsourcing of customer service is less likely to occur because of regulatory restrictions on financial transactions. Even though this centre does not outsource calls involving financial transactions, it does outsource customer 'welcome' calls. In the face of restrictions on subcontracting, the role of the temporary agencies in this firm increases in importance as a way to help reduce labour costs of indefinite contracts, and to increase the quality of the hiring process.

Other in-house centres, for example in the telecommunications industry, face intense competitive pressures and encounter few obstacles to outsourcing work. However, as one manager explained, customer service 'is a competitive advantage' for this firm, and therefore they will not outsource this function. Instead, the firm expanded the role of temporary agencies, involving them in the hiring and selection process, initial training, and coaching. One manager explained the importance of the temporary agency workers: 'people feel more secure when the flexible workers are around'. In this centre, there are four job tiers that increase in complexity, those serving pre-paid customers, post-paid customers, business customers and data customers. Beyond basic training and sales 
training provided by the temporary agency, agents also receive upgrading training on a regular basis from the call centre.

The telecommunications call centre, like other users of temporary agency workers, also specifies the temporary agency labour expenditures, the quality of applicants, the level of evaluation agents are expected to achieve at the three- and six-month points in the contract, the number of people needed in a specific amount of time, acceptable rates of turnover and absenteeism. Evaluations for agents hired through the agency are performed by a supervisor from the telecommunications call centre and a representative from the agency. Consistent with the financial services example, the involvement of the temporary agency offers the telecommunications call centre an opportunity to shift some labour costs and pressures associated with employee turnover to the temporary agency.

In contrast to this call centre, evidence from a second telecommunications company that participated in our study revealed an alternative strategy for managing competitive pressures. Here, agents are also hired initially as temporary workers from one dedicated temporary employment agency, which has staff onsite at the call centre who evaluate applicants for agent positions. In this centre, turnover is viewed positively because, as one manager explains, 'agents on the phone are good for about two to three years. Then people have to leave after they reach that point ... Agents who have been around longer want more money whereas fresh agents are cheaper.' Consistent with the other in-house centres, jobs in the call centre are a gateway to other career opportunities in the firm: 20 percent of the attrition that this call centre experiences involves agents moving to internal careers in marketing and sales (interview data). Although both telecommunications call centres perform the same type of work, as in the financial services centre this firm outsources its late-night calls to a subcontractor centre.

In in-house centres, strong sectoral collective agreements for direct hires enhance the importance of the buffer provided by temporary agencies. Still, temporary agency workers employed in in-house centres are better off than their counterparts in subcontracting centres, because the temporary agency sector agreement governs the terms of their employment, which has higher standards than the subcontractor agreement, and because they have better opportunities to become full-time, permanent workers in those firms.

In contrast to in-house centres, where we found some evidence of good secondary jobs, agents in subcontractor call centres perform similar work to their in-house counterparts yet under very different working conditions - lower skill levels, less training and few advancement opportunities. Part of the explanation for this difference originates in the intense cost pressures subcontractor centres encounter, because they need to be able to offer firms cost savings to attract work from the in-house 
segment. The relatively weak WGCC collective agreement - compared to the temporary agency agreement - creates an incentive for subcontractor centres to use it for temporary agency workers. Some subcontractors prefer the WGCC agreement for temporary workers because it allows them to avoid paying employees a premium for working night hours, a benefit that they would receive if they were covered by the temporary agency agreement.

In one subcontractor centre handling multiple clients - an outbound project, an inbound project and an IT project - the role of the temporary agency was less integrated into the employment system compared with in-house centres. One site director of a subcontractor call centre explains this decision: 'I have not met a temp agency that does assessment well. I interviewed some applicants and eight of them did not know what agency they came from. Agencies pretend they do assessment.' Both selection and training are handled by employees of the subcontractor centre.

This subcontractor avoids long-term relationships with temporary employment agencies such as we found in the in-house segment, but they use temporary employment agencies when they need to add staff quickly for short projects. In such circumstances, this subcontractor will invite two preferred suppliers and one non-preferred supplier to submit bids for a job. The agency that is selected will then find available applicants. Some of the firms for which this subcontractor provides customer service prohibit the use of temporary agencies. Instead, the individuals are hired directly by the subcontractor onto a fixed-term contract until they progress to an indefinite contract. In contrast to the in-house case, temporary employment agencies assume a much more traditional role, and, as this case illustrates, how a project is staffed can be influenced by the service agreement between a subcontractor call centre and a client firm.

In a second subcontracting firm that participated in our study, we found some similarities and differences from the previous example. First, this subcontractor had contracts with four temporary agencies that are involved in recruitment and selection. The subcontractor trained the new hires, and training ranges from half a day to four weeks or more. Second, temporary agents in this centre are covered by the temporary agency sector agreement. This decision may be motivated by the turnover problems this firm was experiencing -10 percent during the first weeks of employment and 4-5 percent thereafter (interview data).

The characteristics of employment systems in subcontractor call centres also influence the demographic composition of the workforce attracted to these jobs. We find that subcontractor call centres employ a considerably higher number of young people than in-house call centres. For example, 39 percent of all agents employed in subcontractor centres are under 25 years of age, compared to only 24 percent in in-house centres. This means that a larger proportion of employees in subcontractor call 
centres may be subject to the lower statutory minimum wage for young people under 23.

We found that 52 percent of Dutch call centre agents have completed a higher level of secondary education - hoger algemeen voortgezet onderwijs (HAVO), voorbereidend wetenschappelijk onderwijs (VWO) or middelbaar beroepsonderwijs (MBO). Given the concentration of students in the subcontractor call centre workforce, it follows logically that the workforce has completed a higher level of education compared to the in-house workforce: 24 percent in subcontractor centres have studied at college or university level compared with 15 percent in in-house call centres as shown in Table 2. The latter may be related to the specific nature of the services usually rendered by subcontractor call centres, such as providing IT help-desk services. Another explanation for this difference may be that the agents employed in subcontractor call centres are more likely to be students who are in the process of completing their studies, or people who temporarily accept a job in a call centre to bridge the time between graduation and finding a job that matches their educational training.

Evidence from centres operating within the Dutch industrial relations system reveals important insights about how labour market institutions shape employment practices at the workplace level. Call centre employers can easily build flexibility into their workforce. Like in-house call centres, subcontractors also have some choice over which collective agreement will cover agents hired through temporary agencies. In contrast to the in-house centres, the difference in the level of employee protection is wider when comparing the WGCC contract with the temporary agency sector agreement. Although it is desirable from the industrial relations perspective to have subcontractor call centres covered by a collective agreement, it has also created a way for them to avoid the stronger regulations defined by the temporary agency sector agreement.

As the evidence illustrates, in-house and subcontractor call centres in the Netherlands have access to workforce flexibility within the Dutch industrial relations system. On the one hand, the availability of a flexible workforce helps address demand fluctuations that call centres encounter. On the other hand, when individuals enter a temporary job, the opportunity for transition from a fixed-term to indefinite contract exists but at the same time, temporary workers during the initial period of an assignment can be dismissed at will. Pay in both in-house and subcontractor call centres is relatively low, despite coverage by collective agreements, but this may indicate the weakness of unions in both the temporary agency sector and in call centres (Lloyd et al., forthcoming). High turnover levels in call centres may indicate that most workers on flexible contracts do not progress to an indefinite contract (de Grip et al., 2005). Call centres in other European countries have less access to 
a flexible workforce, creating an incentive for them to bypass existing industrial relations institutions, for example by establishing subsidiaries, as in Germany (Doellgast et al., this issue).

\section{Conclusions}

The inclusiveness of the Dutch industrial relations system helps to reduce differences in working conditions, and provides employers with access to a flexible workforce while at the same time protecting the security of those in flexible employment relationships. This institutional framework enables employers to bypass the restrictiveness of dismissal regulations for those on indefinite contracts, for example by hiring temporary workers through agencies. Temporary agency workers have some stability because of the four-phase system: as their tenure with a user firm increases, so does the stability of their employment relationship and the likelihood that they will receive subsequent contracts, and ultimately an indefinite contract.

Nonetheless, as our case studies show, differences in negotiated agreements covering in-house workers, subcontractors and temporary agency workers leads to persistent differences in labour market conditions. We found evidence of four tiers of jobs. In-house call centres provide investment in training and advancement opportunities. In the in-house centres, long term relationships with temporary employment agencies give user firms access to a consistent supply of workers who buffer agents directly hired by the user firm, and also work under the temporary agency agreement, which has lower standards than the user firm's agreement. In-house centres offer significantly more training to such agents, and temporary employment agencies help to defray some of the costs associated with the investment in training, and coaching of temporary workers. Meanwhile, in the subcontractor segment, the characteristics of secondary jobs are worse. That is, these jobs require lower skill levels and less training, and provide few opportunities for advancement. The weaker WGCC agreement offers subcontractor employers the opportunity to hire temporary workers under an agreement providing fewer protections than the temporary agency sector agreement, creating a dichotomy in the secondary labour market. In addition, subcontractor firms are under much more intense cost pressures.

The existence of the subcontractor agreement represents a step toward integration into the Dutch industrial relations system, but it also created a loophole that employers can exploit. The development of a subcontractor collective agreement, first negotiated between WGCC and FNV Bondgenoten, also reveals some of the tensions that can arise when trying to bring a new sector into the existing system. The efforts to 
develop this agreement resemble those undertaken in France and Austria to develop collective agreements for subcontractor call centres.

Beyond the differences between the collective agreements, we show that this segmentation is, to some degree, facilitated by temporary employment agencies. In in-house centres, temporary employment agencies have long-term relationships with user firms, reflecting the more stable nature of the business model and lower cost pressures compared with subcontractor call centres. In in-house centres, where agents receive significantly more training and coaching than in subcontractor call centres, temporary agencies may be directly involved in screening, training and coaching temporary agency workers. By contrast, in subcontractor centres the emphasis is on getting agents into their seats quickly to staff projects, rather than coaching and developing them. The limited promotion opportunities in subcontractor firms translate into a reluctance to develop agents for long-term employment; indeed those with longer tenure are viewed as undesirable because they are more expensive.

The Dutch industrial relations system gives employers access to a flexible workforce but also yields contradictions for the call centre workforce. On the one hand, it features a high level of collective bargaining coverage and an intricate system of legislative rights. On the other hand, as our evidence shows, it creates differentiated job structures and working conditions for those performing similar kinds of work. The dynamics of power and the strategies among social actors will determine the future configuration of jobs and working conditions in this sector.

\section{ACKNOWLEDGEMENTS}

We gratefully acknowledge generous financial support from the Ministerie van Sociale Zaken en Werkgelegenheid (Ministry of Social Affairs and Employment), the Russell Sage Foundation and the University of British Columbia for funding the research. We also thank the four reviewers for comments and suggestions on earlier versions of this article.

\section{REFERENCES}

Arrowsmith, J. (2006) Temporary Agency Work in an Enlarged European Union. Luxembourg: Office for Official Publications.

Bain, P. and Taylor, P. (2002) 'Consolidation, "Cowboys" and the Developing

Employment Relationship in British, Dutch and US Call Centres', in

U. Holtgrewe, C. Kerst and K. Shire (eds) Re-Organising Service Work:

Call Centres in Germany and Britain, pp. 42-62. Aldershot: Ashgate.

Batt, R. and Moynihan, L.M. (2002) 'The Viability of Alternative Call Centre

Production Models', Human Resource Management Journal 12: 14-34. 
Béraud, M., Colin, T. and Grasser, B. (2008) 'Job Quality and Career Opportunities for Call Center Workers: Contrasting Patterns in France’, in E. Caroli and J. Gautié (eds) Low-Wage Work in France, pp. 254-87. New York: Russell Sage Foundation.

de Grip, A., Sieben, I. and van Jaarsveld, D. (2005) Employment and Industrial Relations in the Dutch Call Center Sector. Maastricht: ROA.

Dekker, R., de Grip, A. and Heijke, H. (2002) 'The Effects of Training and Overeducation on Career Mobility in a Segmented Labour Market', International Journal of Manpower 23(2): 106-25.

Doellgast, V. and Greer, I. (2007) 'Vertical Disintegration and the Disorganization of German Industrial Relations', British Journal of Industrial Relations 45(1): 55-76.

Doeringer, P.B. and Piore, M.J. (1971) Internal Labor Markets and Manpower Analysis. Lexington, MA: Heath.

Gumbrell-McCormick, R. and Hyman, R. (forthcoming) 'Works Councils: The European Model of Industrial Democracy', in A. Wilkinson, P. Gollan, M. Marchington and D. Lewin (eds) Oxford Handbook of Participation in Organizations. Oxford: Oxford University Press.

Hemerijck, A.C. and Vail, M.I. (2006) 'The Forgotten Center: The State as Dynamic Actor in Corporatist Political Economies', in J.D. Levy (ed.) The State after Statism: New State Activities in the Age of Liberalization, pp. 57-82. Cambridge, MA: Harvard University Press.

Holst, H. (2008) 'The Political Economy of Trade Union Strategies in Austria and Germany: The Case of Call Centres', European Journal of Industrial Relations 14(1): 25-45.

Koene, B., Paauwe, J. and Groenewegen, J. (2004) 'Understanding the Development of Temporary Agency Work in Europe', Human Resource Management Journal 14(3): 53-73.

Lloyd, C., Weinkopf, C. and Batt, R. (forthcoming) 'Restructuring Customer Service: Labor Market Institutions and Call Centre Workers in Europe and the US', in J. Gautié and J. Schmidt (eds) Low-Wage Work in Europe. New York: Russell Sage Foundation.

Looise, J.K. and Drucker, M. (2003) 'Dutch Works Councils in Times of Transition: The Effects of Changes in Society, Organizations and Work on the Position of Works Councils', Economic and Industrial Democracy 24(3): 379-409.

SER (2007) Industrial Relations and the Adaptability of the Dutch Economy. The Hague: SER.

Storrie, D. (2002) Temporary Agency Work in the European Union. Dublin: European Foundation.

Streeck, W. (1995) 'Works Councils in Western Europe: From Consultation to Participation', in J. Rogers and W. Streeck (eds) Works Councils: Consultation, Representation, and Cooperation in Industrial Relations, pp. 313-50. Chicago, IL: University of Chicago Press.

Teulings, C. and Hartog, J. (1998) Corporatism or Competition?: Labour Contracts, Institutions and Wage Structures in International Comparison. Cambridge: Cambridge University Press. 
Tijdens, K., van Klaveren, M., Houwing, H., van der Meer, M. and van Essen, M. (2006) 'Temporary Agency Work in the Netherlands', working paper 2006-54, University of Amsterdam.

van der Meer, M., Visser, J. and Wilthagen, T. (2005) 'Adaptive and Reflexive

Governance: The Limits of Organized Decentralization', European Journal of Industrial Relations 11(3): 347-65.

van Jaarsveld, D. (2004) 'Collective Representation among High-Tech Workers at Microsoft and Beyond: Lessons from WashTech/CWA', Industrial Relations 43(2): 364-85.

van Klaveren, M. and Sprenger, W. (2008) 'Call Center Employment:

Diverging Jobs and Wages', in W. Salverda, M. van Klaveren and M. van der Meer (eds) Low-Wage Work in the Netherlands, pp. 237-66. New York: Russell Sage Foundation.

Visser, J. (1995) 'The Netherlands: From Paternalism to Representation', in J. Rogers and W. Streeck (eds) Works Councils: Consultation, Representation, and Cooperation in Industrial Relations, pp. 79-114. Chicago, IL: University of Chicago Press.

Visser, J. (1998) 'The Netherlands: The Return of Responsive Corporatism', in A. Ferner and R. Hyman (eds) Changing Industrial Relations in Europe, 2nd edn, pp. 283-314. Oxford: Blackwell.

Visser, J. (2002) 'The First Part-Time Economy in the World: A Model to Be Followed?', Journal of European Social Policy 12(1): 23-42.

Visser, J. and Hemerijck, A. (1997) 'A Dutch Miracle': Job Growth, Welfare Reform and Corporatism in the Netherlands. Amsterdam: Amsterdam University Press.

DANIELLE VAN JAARSVELD is Assistant Professor at the Sauder School of Business, University of British Columbia.

ADDRESS: Sauder School of Business, University of British Columbia, 2053 Main Mall, Vancouver, BC, Canada V6T 1 Z2.

[e-mail: vanjaarsveld@sauder.ubc.ca]

ANDRIES DE GRIP is Professor of Economics at the Research Centre for Education and the Labor Market (ROA), Maastricht University and Research Fellow at the Institut zur Zukunft der Arbeit (IZA), Bonn.

ADDRESS: ROA, Maastricht University, PO Box 616, 6200 MD Maastricht, The Netherlands. [e-mail: a.degrip@maastrichtuniversity.nl]

INGE SIEBEN is Senior Researcher at the Department of Sociology, Tilburg University.

ADDRESS: Departement Sociologie, Tilburg University, PO Box 90153, 5000 LE Tilburg, The Netherlands. [e-mail: i.j.p.sieben@uvt.nl] 